\title{
THE EFFECT OF SOIL SURFACTANTS ON SOIL HYDROLOGICAL BEHAVIOR, THE PLANT GROWTH ENVIRONMENT, IRRIGATION EFFICIENCY AND WATER CONSERVATION
}

\author{
DEMIE MOORE ${ }^{\left.1,3^{*}\right)}$, STANLEY J. KOSTKA ${ }^{1)}$, THOMAS J. BOERTH ${ }^{1)}$, MICA FRANKLIN $^{1)}$, \\ COEN J. RITSEMA ${ }^{2,3)}$, LOUIS W. DEKKER ${ }^{2)}$, KLAAS OOSTINDIE ${ }^{2)}$, \\ CATHELIJNE STOOF ${ }^{3)}$, JAN WESSELING ${ }^{2)}$ \\ ${ }^{1)}$ Aquatrols, 1273 Imperial Way, Paulsboro, NJ 08066 USA; *) Corresponding author, Mailto: demie.moore@aquatrols.com; \\ stan.kostka@aquatrols.com; tom.boerth@aquatrols.com; mica.franklin@aquatrols.com; \\ ${ }^{2)}$ Alterra Soil Research Center, P.O. Box 47, 6700 AA Wageningen, The Netherlands; \\ Mailto: coen.ritsema@wur.nl; louis.dekker@wur.nl; klaas.oostindie@wur.nl; jan.wesseling@wur.nl; \\ ${ }^{3)}$ University of Wageningen, P.O. Box 47,6700 AA Wageningen, The Netherlands; Malto: cathelijne.stoof@wur.nl
}

Soil water repellency causes at least temporal changes in the hydrological properties of a soil which result in, among other things, suboptimal growing conditions and increased irrigation requirements. Water repellency in soil is more widespread than previously thought and has been identified in many soil types under a wide array of climatic conditions worldwide. Consequences of soil water repellency include loss of wettability, increased runoff and preferential flow, reduced access to water for plants, reduced irrigation efficiency, increased requirement for water and other inputs, and increased potential for non-point source pollution. Research indicates that certain soil surfactants can be used to manage soil water repellency by modifying the flow dynamics of water and restoring soil wettability. This results in improved hydrological behavior of those soils. Consequently, the plant growth environment is also improved and significant water conservation is possible through more efficient functioning of the soil.

KEY WORDS: Soil water repellency, Irrigation Efficiency, Runoff, Preferential Flow, Soil Wetting Agents, Soil Surfactants, Water Conservation.

Demie Moore, Stanley J. Kostka, Thomas J. Boerth, Mica Franklin, Coen J. Ritsema, Louis W. Dekker, Klaas Oostindie, Cathelijne Stoof, Jan Wesseling: VPLYV POVRCHOVO AKTÍVNYCH LÁTOK NA HYDROLOGICKÉ PROCESY V PÔDE, RAST RASTLÍN, ZÁVLAHY A RETENCIU VODY V PÔDE. J. Hydrol. Hydromech., 58, 2010, 3; 29 lit., 5 obr.

Vodoodpudivost' pôdy spôsobuje prinajmenšom dočasné zmeny v hydrologických vlastnostiach pôdy, ktoré okrem iného môžu viest' k suboptimálnym podmienkam rastu rastlín a k zvýšenej potrebe závlah. Vodoodpudivost' pôdy je rozšírenejší jav, ako sa pôvodne predpokladalo; bola identifikovaná v mnohých pôdnych typoch a klimatických podmienkach na celom svete. Dôsledkom vodoodpudivosti pôdy je strata zmáčavosti, zvýšený povrchový odtok a preferenčné prúdenie, znížená dostupnost' vody a iných vstupov pre rastliny, znížený účinok závlah, zvýšené požiadavky na vodu a iné vstupy, ako aj zvýšené riziko plošného znečistenia. Výskum naznačuje, že niektoré povrchovo aktívne látky (soil surfactants) môžu upravit' vodoodpudivost' pôdy obnovením omáčania a modifikáciou dynamiky vody. Výsledkom je zlepšenie hydrologických vlastností pôdy. Podobne, výsledkom je zlepšenie prostredia pre rast rastlín, zvýšenie retencie vody v pôde a teda aj efektívnejšia funkcia pôdy.

KLÚČOVÉ SLOVÁ: vodoodpudivost' pôdy, efektívnost' závlahy, povrchovo aktívne látky, preferované prúdenie, retencia pôdy.

\section{Introduction}

Factors affecting soil hydrological behavior, especially the development of soil water repellency (SWR), can lead to suboptimal growing conditions and increased irrigation requirements. SWR leads to reduction or loss of soil wettability causing at least temporal changes in the hydrological properties of a soil. Consequences include increased runoff and preferential flow, reduced access to water 
for plants, reduced irrigation efficiency, increased requirement for water and other inputs, and increased potential for non-point source pollution. Restoration of soil wettability will improve the hydrological behavior of soils allowing increased irrigation efficiency and significant water conservation in irrigated crop and landscape systems.

Soil surfactants can be used to improve the wettability of soils. Soil surfactants are materials that lower the surface tension of water and, depending upon formulation, can also restore wettability to water repellent mineral or organic soils. Since the invention of the original soil surfactant, AquaGro, in the 1950's, there have been many advances in soil surfactant formulation making their use more economically viable for a variety of cropping systems. Where soil wettability is less than optimal, soil surfactants in combination with appropriate irrigation and soil cultivation practices can improve soil hydrological behavior resulting in improved irrigation efficiency and water conservation (Kostka et al., 2007).

A growing body of research shows that SWR and associated preferential flow are more common than previously thought - and that application of soil surfactants is an effective remediation strategy (Dekker et al., 2005). This paper summarizes the findings citing some of the recent research results.

\section{Soil water repellency and preferential flow}

SWR is a condition that develops in soils causing the soil to resist wetting. It is caused by the accumulation of water repellent/hydrophobic coatings on soil particle surfaces (Dekker et al., 2001; Hallett et al., 2001; Karnok and Tucker, 2002), and triggered when a soil drops below a certain critical soil moisture content for that particular soil (Dekker and Ritsema, 1994). A direct consequence of SWR is a reduction in a soil's ability to wet and retain water (Hallett, 2007).

The development of water repellent behavior in soils is more wide-spread than previously thought. Among the first to mention water repellency were Schreiner and Shorey in North America (1910) who wrote: "...there was found in California a soil which could not be properly wetted, either by man, by rain, irrigation, or movement of water from the subsoil, with the result that the land could not be used properly for agriculture. On investigation it was found that this peculiarity of the soil was due to the organic material, which when extracted had the properties of a varnish - repelling water to an extreme degree." Since that time, water repellent soils have been identified in a wide variety of soils worldwide and studied in 35 countries on six continents (Dekker et al., 2005). Dekker et al. (2001) and Karnok and Tucker (2002) also report that SWR develops under a wide range of different plant systems. All of this has lead researchers to the view that occurrence of SWR seems to be more the norm than exception (Wallis and Horne, 1992; Ritsema and Dekker, 2005).

Preferential flow refers to the movement of water and solutes through specific pathways in only a portion of the soil matrix rather than in a more uniform wetting front as expected from lateral diffusion of water in the soil. Because SWR reduces the wettability of portions of the soil, it leads to the development of preferential flow paths (Dekker et al., 2001). The preferential flow paths often carry applied water and solutes past the active root zone, reducing efficiency of both precipitation and irrigation, limiting plant available water and increasing environmental risk.

As noted, soil scientists and hydrologists now consider water repellency and preferential flow to be more the norm than the exception in a wide variety of soils (Dekker et al., 2005). Water repellency in soil and the associated preferential flow are like "barriers" and "leaks" in the soil plumbing system respectively. Their occurrence interferes with the soils ability to effectively capture and distribute rainfall or irrigation water for plant use. It has been observed as well that, even after extended wet periods, SWR and preferential flow paths recur (Oostindie et al., 2005). Even low levels of repellency can cause reduced infiltration and retention, increased runoff, variable wetting and preferential flow. These lead to, among other things, suboptimal growing conditions, reduced irrigation efficiency and increased water requirements.

The development of water repellency in soil can be detected by a variety of methods, the most common of which is the Water Drop Penetration Time (WDPT) test. There are advantages and disadvantages to the various approaches (Hallett, 2007). To quickly and easily determine the presence of SWR for applied purposes like irrigation management, the WDPT test has many advantages. This method is spelled out in detail in the new Soil Science Society of America publication, Soil Science - Step-by-Step Field Analysis (Ritsema et al., 2008).

Soil surfactants are capable of improving soil hydrological behavior by correcting or preventing 
water repellency, and reducing and preventing preferential flow. The result is improved growing environments, more efficient irrigation, reduced environmental risk from preferential flow and water savings of up to $30 \%$ or more. This has been extensively studied and documented in turfgrass management (Cisar et al., 2000; Karnok and Tucker 2002; Park et al., 2004; Dekker et al., 2005; Oostindie et al., 2005; Karcher et al., 2006; Aamlid et al., 2009; Hallet, 2007; Leinauer et al., 2007) and is now being explored in agricultural crops as well (Hopkins and Cook, 2007; Speth et al., 2005; Rowland et al., 2007). Fig. 1 shows the effect of a soil surfactant on water content, wettability and preferential flow in a repellent sandy soil on a golf course in the Netherlands.
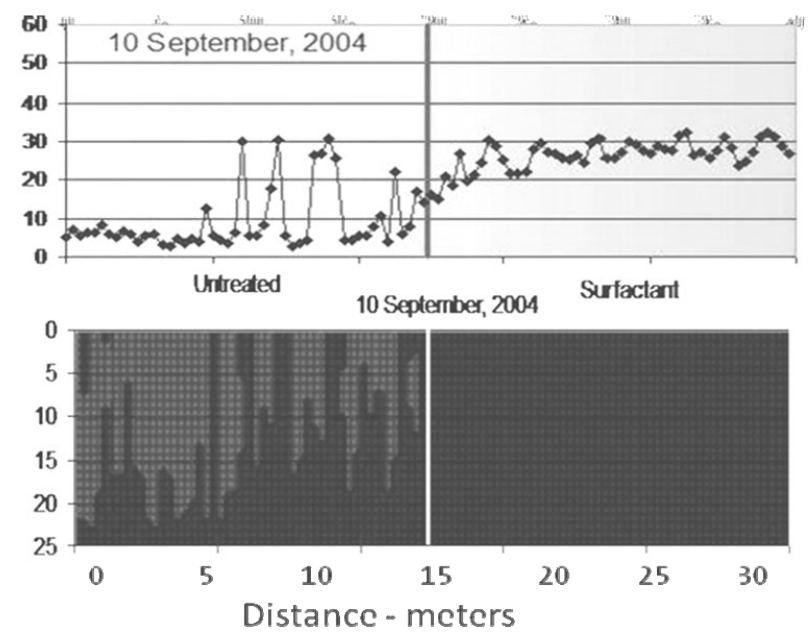

Fig. 1. Effect of surfactant (Revolution) on water content and water repellency/preferential flow in a sandy fairway of Golf Club De Pan, NL. Top - Volumetric water content [\%] in the upper $5[\mathrm{~cm}]$ measured by TDR at intervals of $25[\mathrm{~cm}]$; Bottom - Actual soil water repellency in top (25) cm of fairway measured by Water Drop Penetration Time test at $25(\mathrm{~cm})$ intervals. WDPT for data of the left part of the picture is $>5 \mathrm{sec}-$ onds, for right part of the picture $<5$ seconds (Oostindie et al., 2005).

Obr. 1. Vplyv povrchovo aktívnych látok na obsah vody a vodoodpudivost'/preferované prúdenie na piesočnatej hracej ploche Golf Club De Pan, NL. Hore - obsah vody v jednotkách objemu [\%] $\mathrm{v}$ hornej 5-cm vrstve pôdy meranej TDR $\mathrm{v}$ intervaloch po $25 \mathrm{~cm}$; Dolu - aktuálna vodoodpudivost' pôdy vo vrchnej, 25-cm vrstve hracej plochy meranej "Water Drop Penetration Time" (WDPT) testom v 25-cm intervaloch dížky. WDPT pre bledšie oblasti (l'avá čast' obr.) je $>5 \mathrm{~s}$, pre tmavšie oblasti (pravá čast' obr.) $<5 \mathrm{~s}$ (Oostindie et al., 2005).

\section{Runoff}

Runoff of irrigation or rainfall results in a loss of water which is wasteful, raises the risk of pollution and erosion, and increases irrigation requirements.
Runoff is increased when water is applied at excessive precipitation rates or when infiltration is reduced. While compaction has long been recognized as a cause of reduced infiltration, SWR is another cause of reduced infiltration and increased runoff. This has been verified in numerous studies (Dekker et al., 2005). And while this consequence has been recognized for some time in the case of severe water repellency, it has more recently been discovered to also occur with very low levels of repellency as well (Hallett et al., 2001).

Soil surfactants have been shown to increase infiltration into soils and reduce runoff significantly. Morgan, Letey and others observed this in early research with surfactants in the 1960's (Morgan et al., 1966). More recent research has documented reductions in runoff on a range of surfactant treated soils under a variety of slope angles. A $19.4 \%$ reduction in runoff on a surfactant treated clayey Crosby soil with a $4 \%$ slope was documented by Sepulveda (2004). Oostindie et al. (2005) recorded reduced runoff and increased soil moisture on a water repellent sand in a sloped fairway that had been treated with a soil surfactant. On loamy sand with an $8 \%$ slope, Mitra et al. (2006) found that soil surfactant applications doubled the time to runoff, from 20 minutes to more than 40 minutes, and total runoff was reduced more than $30 \%$ (Fig. 2). By reducing runoff, soil surfactants can improve the amount of water reaching the root zone, increase efficiency of irrigation and reduce irrigation requirements and the potential for contaminants to enter surface waters or storm water systems.

Time to Runoff on Loamy Sand on $8 \%$ Slope

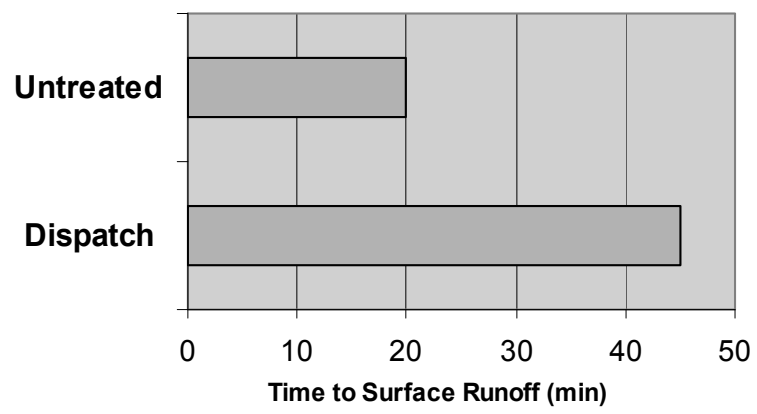

Fig. 2. Average irrigation time to runoff in a loamy sand on an $8 \%$ slope as affected by the soil surfactant "Dispatch" (from Mitra et al., 2006).

Obr. 2. Priemerný časový interval od času závlahy po odtok $\mathrm{v}$ hlinitej pôde so sklonom $8 \%$ a jeho ovplyvnenie povrchovo aktívnou látkou "Dispatch" (Mitra et al., 2006). 


\section{Infiltration and root zone wetting}

Infiltration and root zone wetting are fundamental to plant available water, effective irrigation and irrigation efficiency. When soils function as expected, infiltration and root zone distribution of applied water will be fairly uniform. This will result in relatively high distribution uniformity (DU) in the soil as well as on the surface as is generally expected. However, SWR can interfere with infiltration and water distribution in soil resulting in significant variation in moisture content throughout the root zone (Dekker and Ritsema, 1994; Park et al., 2005). This has been found to be true in many soils such as sand, loam, clay and peat (Dekker et al., 2001; Dekker et al., 2005). Hallett et al. (2004) have also found this to be true even at low, "subcritical", levels of SWR. When infiltration is compromised by SWR, root zone DU can be lower than irrigation DU on the surface, leading to reduced irrigation efficiency.

In addition to reduced efficiency in water distribution in the root zone, preferential flow paths can form. This occurs as the repellent parts of the soil, which are not wetted, become drier and the wettable areas become the channels through which water and solutes are transported (Dekker et al. 2001). As a result, a significant portion of the water and solutes intended for the root zone will bypass it instead (Dekker and Ritsema, 1994; Ritsema et al., 2001). In addition to reducing water available for plants, this increases waste, irrigation requirements and the risk of environmental contamination by solutes reaching groundwater faster than expected.

Since soil surfactants reduce SWR and facilitate wetting, their use in soils with even subcritical water repellency can lead to significant improvements in infiltration and root zone DU. Park et al. (2004), among others, report significantly reduced repellency and improved wettability when surfactants are applied regularly. In a very water repellent sand, Oostindie et al. (2005) report significantly more consistent moisture levels and, correspondingly, much lower coefficients of variation in surfactant treated soils (average variation 10.4\%) compared to adjacent untreated soil during the same period (average variation $>50 \%$ ) (Fig. 3). Reducing water repellency and increasing soil wettability and root zone distribution uniformity improves the plant growth environment, reduces irrigation requirement, preferential flow and associated environmental risk (Oostindie et al., 2005; Park et al., 2005; Karcher et al., 2006; Aamlid et al., 2009).

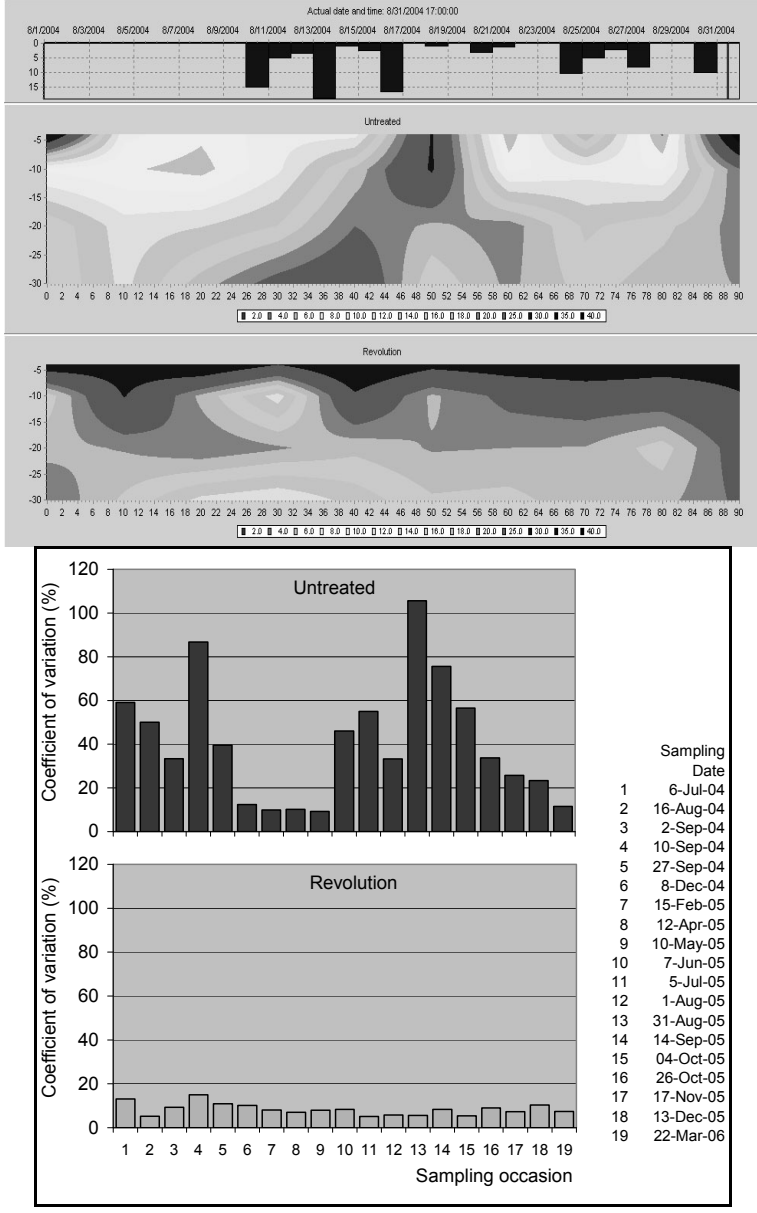

Fig. 3. Actual volumetric water content $[\%]$ on one date in a sandy soil managed and not managed with soil surfactant (Revolution) measured with installed TDR probes to a depth of $30 \mathrm{~cm}$ (Top untreated, bottom treated), and coefficients of variation during the course of the experiment (Oostindie et al., 2005).

Obr. 3. Obsah vody v pôde v jednotkách objemu [\%] meraný $\mathrm{v}$ tom istom čase $\mathrm{v}$ piesočnatej pôde $\mathrm{s}$ aplikáciou povrchovo aktívnej látky ("Revolution") a bez nej, meraný inštalovanými TDR meračmi do híbky $30 \mathrm{~cm}$ (hore bez aplikácie povrchovo aktívnej látky, dole s aplikáciou), a koeficienty variácie počas experimentu (Oostindie et al., 2005).

\section{Plant available water}

The Irrigation Association in the United States defines irrigation as intentional application of water to provide water to plants for crop production or sustained growth (Rochester, 2006). Plant available water (PAW), the available water located in the root zone, is therefore an important aspect of irrigation management and efficiency. As PAW values for use in irrigation scheduling are calculated from expected soil water holding capacity and plant root zone depth (The Irrigation Association, 2003), the actual behavior of the soil will impact the effec- 
tiveness and efficiency of the irrigation events. When PAW is compromised plants do not have access to expected amounts of water, crop quality suffers and/or excess water will be required.

SWR reduces actual PAW because it "locks out" part of the soil's water holding potential. In severe cases SWR can render soils non-usable for crop production (Hallett et al., 2001). In less severe cases, it can cause reduced plant performance (Cisar et al., 2000; Hopkins and Cook, 2007; Leinauer et al., 2007). Unaddressed, this reduced PAW also reduces irrigation efficiency.

The use of soil surfactants to restore soil wettability and increase infiltration, results in improved soil behavior with regard to PAW. This has been documented by an increasing number of researchers working with a variety of crops. Significant increases in soil water contents after treatment with surfactant have been documented by many researchers (Karnok and Tucker, 2001; Hopkins and Cook, 2007; Mitra, 2005; Oostindie et al., 2005). Fig. 4 provides an example in potato hills. Improved crop performance with the same or reduced irrigation, indicating improved PAW, has also been reported in turfgrass maintenance by Cisar et al. (2000), Karnok and Tucker (2001), Mitra (2005), Oostindie et al. (2005), and Park et al. (2004, 2005) among others; and by Hopkins and Cook (2007) with potatoes and Rowland et al. (2007) with peanuts. Managing soil behavior to ensure expected levels of PAW is fundamental to achieving efficiency in irrigation.

\section{Water conservation through efficient irrigation}

Efficient irrigation is impossible without well designed, installed, operated and maintained irrigation systems. Nonetheless, it is also true that how water moves in the soil is key to the plant growth environment, irrigation efficiency, crop performance and water conservation. When water movement into and through soils becomes erratic, even the most well designed and managed irrigation system will fall short of expected and desired goals. More irrigation is then applied because plants exhibit stress, consumption is increased and efficiency of the irrigation program is reduced. In addition to well designed and operated irrigation systems, water can be conserved by increasing the efficiency of water delivery to the soil.
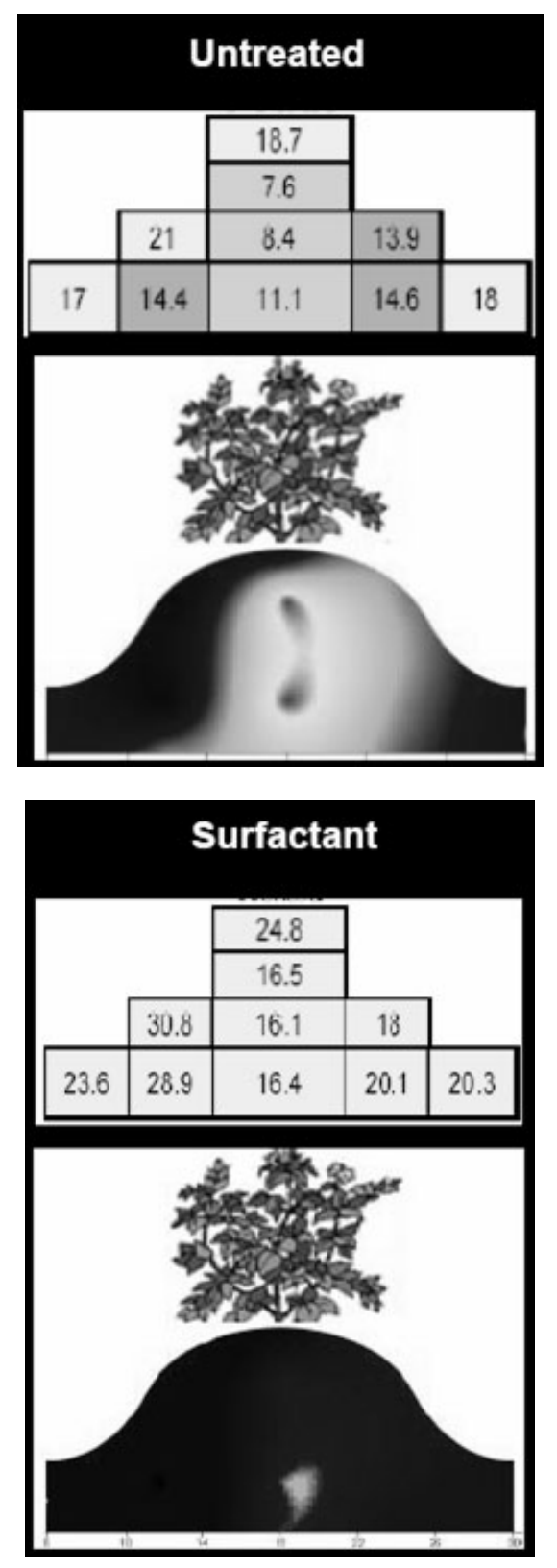

Fig. 4. Effect of soil surfactant on volumetric water content [\%] of sandy potato hill as measured with installed TDR probes (Hopkins and Cook, 2007).

Obr. 4. Vplyv povrchovo aktívnej látky na vlhkost' piesočnatej pôdy na riadku zemiakov, vyjadrenú objemovo [\%]; merané pomocou TDR (Hopkins and Cook, 2007).

Soil surfactants ensure that soils are wettable so that rainfall and irrigation applied at appropriate precipitation rates will infiltrate quickly and uniformly. An increasing amount of research by scientists of varying disciplines is showing that more effective delivery of water to the root zone, especially where soil water repellency is a factor, can result in very significant reductions in water use or requirements. In turfgrass management, reductions 
The effect of soil surfactants on soil hydrological behavior, the plant growth environment, irrigation efficiency ...

of at least 20\% (Kostka et al., 2005; Oostindie et al., 2005) and in some cases more than 50\% (Park et al., 2005; Karcher et al., 2006) have been reported with no loss in turfgrass quality (Fig. 5). A summary of research in this regard was published by Kostka et al. (2007). The use of soil surfactants allows conservation of water and greater irrigation efficiency.

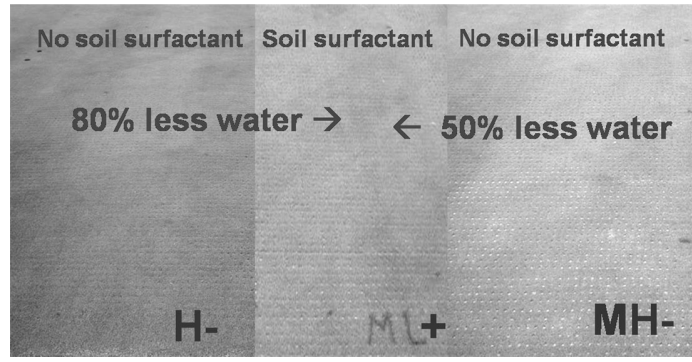

Fig. 5. Effect of soil surfactant on turfgrass quality with reduced irrigation; from Karcher et al., 2006.

Obr. 5. Vplyv povrchovo aktívnej látky na kvalitu trávy s redukovanou závlahou; podl'a Karchera et al., 2006.

\section{Conclusion}

When soil hydrological behavior is affected by water repellency, conditions for plant growth and irrigation efficiency decline leading to either increased water consumption to meet plant needs, or reduced "crop" performance. SWR is more common than previously recognized and, even at very low levels, significantly impacts soil hydrological behavior. Correction or avoidance of SWR keeps soils wettable, improving hydrological behavior and, therefore, the plant growth environment, irrigation efficiency, crop performance and efficiency of water use.

The development of water repellency can be detected using the Water Drop Penetration Time test. Once detected, water repellency can be managed with use of soil surfactants to improve efficiency of the irrigation. Soils that have a critical water content threshold for water repellency seem to remain susceptible to water repellency below that moisture level, even after long wet periods or remediation efforts. Therefore, especially during drier periods, water repellency can be expected to recur in areas where it has been previously detected.

Soil surfactants are a management technology for reducing, and possibly avoiding development of, water repellency and associated preferential flow. The result is maintenance or restoration of soil wettability and improved infiltration and root zone distribution uniformity. Research worldwide is increasingly indicating that certain soil surfactant formulations significantly improve soil hydrological behavior allowing more efficient irrigation, improvement in crop response and significant reductions in water consumption. Further research regarding managing soil hydrological behavior with surfactants and development and use of irrigation and moisture sensor technology holds promise for achievement of new levels of irrigation and water use efficiency in irrigated crop and landscape systems.

\section{REFERENCES}

AAMLID T.S., LARSBO M., JARVIS N., 2009: Effects of surfactant use and peat amendment on leaching of fungicides and nitrate from golf greens. Biologia, 64, 3, 419-423.

CISAR J.L., WILLIAMS K.E., VIVAS H.E., HAYDU J.J., 2000: The occurrence and alleviation by surfactants of soil water repellency on sand-based turfgrass systems. J. Hydrol., 231-232, 352-358, doi 10/1016/S0022-1694(00) 00207-9.

DEKKER L.W., RITSEMA C.J., 1994: How water moves in a water repellent sandy soil 1 . Potential and actual water repellency. Wat. Resour. Res., 30, 2507-2517.

DEKKER L.W., OOSTINDIE K., ZIOGAS A.K., RITSEMA C.J., 2001:. The impact of water repellency on soil moisture variability and preferential flow. Int. Turfgrass Soc. Res. J., 9, 498-505.

DEKKER L.W., OOSTINDIE K., RITSEMA C.J., 2005: Exponential increase of publications related to soil water repellency. Aus. J. of Soil Res., 43, 403-441.

HALLET P.D., 2007: An introduction to soil water repellency. Proc. 8th International Symposium on Adjuvants for Agrochemicals (ISAA2007), Columbus, OH, Aug. 6-9, 2007, $13 \mathrm{p}$.

HALLETT P.D., DOUGLAS J.T., RITZ K., WHEATLEY R.E., YOUNG I.M., 2001: Plant root and microbial derived soil water repellency. Scottish Crop Research Institute Annual Report 2000/2001, pp. 148-151.

HALLETT P.D., NUNAN N., DOUGLAS J.T., YOUNG I.M., 2004: Millimeter-scale spatial variability in soil water sorptivity: scale, surface elevation, and subcritical repellency effects. Soil Sci. Soc. Am. J., 68, 352-358.

HOPKINS B.G., COOK A.G., 2007: Water repellent soils in potato production. ASA-CSSA-SSSA Annual Meetings Abstracts (2007) 329-11; <website> (meeting program online).

KARCHER D., MILLER J., RICHARDSON M., LEINAUER B., 2006: Irrigation frequency and soil surfactant effects on a sand-based putting green. International Conference Biohydrology 2006. Prague. http://147.213.145.2/biohydrology/ abstracts/Karcher S3.doc.

KARNOK K.J., TUCKER K.A., 2001: Wetting agent treated hydrophobic soil and its effect on color, quality and root growth of creeping bentgrass. Int. Turfgrass Soc. Res. J., 9, 537-541.

KARNOK K.J., TUCKER K.A., 2002: Water repellent soils Part I. Where are we now? Golf Course Management, 70, 6, 59-62.

KOSTKA S.J., CISAR J.L., RITSEMA C.J., DEKKER L.W., FRANKLIN M.A., MITRA S., McCANN S.E., 2005: Sur- 
factants and soil water repellency in golf course soils - water use and environmental implications. Proc. 25th Irrigation Association Conference, p. 235-246.

KOSTKA S.J., CISAR J.L., MITRA S., PARK D.M., RITSEMA C.J., DEKKER L.W., FRANKLIN M.A., 2007: Irrigation efficiency - Surfactants can save water and help maintain turfgrass quality. Golf Course Industry, 19, 4, 91-95.

LEINAUER B., KARCHER D., BARRICK T., IKEMURA Y., HUBBLE H., and MAKK, J., 2007: Water repellency in sandy root zones treated with wetting agent. USGA Turfgrass and Environmental Research Online, 6, 6, 1-9.

MITRA S., 2005: Water conservation on fairways by systematic injection of wetting agents. California Fairways. July/August, 14, 4, p. 11-12, 14-16.

MITRA S., VIS E., KUMAR R., PLUMB R., FAM M., 2006: Wetting agents and cultural practices increase infiltration and reduce runoff losses of irrigation water. Biologia, Bratislava, 61/Suppl., 19, S353-S357.

MORGAN W.C., LETEY J., RICHARDS S.J., VALORAS N., 1966: Physical soil amendments, soil compaction, irrigation, and wetting agents in turfgrass management I. Effects on compactability, water infiltration rates, evapotranspiration, and number of irrigations. Agronomy J., 58, 5, 525-528.

OOSTINDIE K., DEKKER L.W., RITSEMA C.J., WESSELING J.G., 2005: Effects of surfactant applications on the wetting of sands in fairways of the Dutch golf course De Pan. Wageningen, Alterra Report 1144.

PARK D.M., CISAR J.L., WILLIAMS K.E., SNYDER G.H., 2004: Alleviation of soil water repellency in sand based Bermudagrass in South Florida. A. Horticulturae, 661, 111-115.

PARK D.M., CISAR J.L., MCDERMITT D.K., WILLIAMS K.E., HAYDU J.J., MILLER W.P., 2005: Using red and infrared reflectance and visual observation to monitor turf quality and water stress in surfactant-treated Bermudagrass under reduced irrigation. Int. Turfgrass Soc. Res. J., 10, 115-120.

RITSEMA C.J., DEKKER L.W.: 2005. Behaviour and management of water repellent soils - Preface. Aus. J. of Soil Res., 43, -ii.

RITSEMA C.J., VAN DAM J.C., DEKKER L.W., OOSTINDIE K., 2001: Principles and modeling of flow and transport in water repellent surface layers, and consequences for management. Int. Turfgrass Soc. Res. J., 9, 615-624.

RITSEMA C.J., DEKKER L.W., OOSTINDIE K., MOORE D., LEINAUER B., 2008: Soil Water Repellency and Critical Soil Water Content. Chapter in Soil Science: Step-byStep Field Analysis, pp. 97 - 112. Soil Science Society of America, Madison, WI. Rochester, EW, 2006. Glossary of Irrigation Terms. Irrigation Association website. www.irrigation.org.

ROWLAND D., FAIRCLOTH W., PAYTON P., TISSUE D., 2007: Acclimation response of peanut to deficit irrigation: Pinpointing water application to increase drought tolerance. Abstracts 39th Annual Meeting of the American Peanut Research and Education Society. Hoover, AL, July 10-13, 2007, 2p

SCHREINER O., SHOREY E.C., 2010: Chemical nature of soil organic matter. USDA Bureau Soils Bull., 74, 2-48.

SEPÚLVEDA N.B., 2004: Wetting agents and irrigation water conservation: efficacy for golf course fairways and identification of management practices. M.S. Thesis. Cranfield University. $74 \mathrm{p}$.
SPETH P., LOWERY B., KELLING K., 2005: Use of surfactant to improve water and nitrogen efficiency in potato production on sandy soils. ASA-CSSA-SSSA Annual Meetings Abstracts. THE IRRIGATION ASSOCIATION, 2003: Irrigation Scheduling. Chapter 5 in Principles of Irrigation, IA, Falls Church, VA, p. 98.

WALLIS M.G., HORNE D.J., 1992: Soil water repellency. Advances in Soil Science, 20, 91-146.

Received 7 January 2010

Accepted 23 June 2010

\section{VPLYV POVRCHOVO AKTÍVNYCH LÁTOK} NA HYDROLOGICKÉ PROCESY V PÔDE, RAST RASTLÍN, ZÁVLAHY A RETENCIU VODY V PÔDE

Demie Moore, Stanley J. Kostka, Thomas J. Boerth, Mica Franklin, Coen J. Ritsema, Louis W. Dekker, Klaas Oostindie, Cathelijne Stoof, Jan Wesseling

Vodoodpudivost' pôdy (VP) ovplyvňuje jej hydrologické vlastnosti, podmienky pre rast rastlín a efektívnost' závlah, čo vedie k zvýšeniu potreby vody pre rastliny, alebo k redukovanej produkcii biomasy. Výskyt VP je častejší ako sa v minulosti predpokladalo; jeho výskyt aj v nízkych úrovniach môže významne ovplyvnit' hydrologické procesy v pôde. Odstránenie, alebo zníženie VP vedie $\mathrm{k}$ zmáčavej pôde, $\mathrm{k}$ zlepšeniu jej hydrologických vlastností, k zlepšeniu prostredia rastu rastlín, k zvýšeniu efektívnosti závlah, k zvýšenej produkcii biomasy a k zvýšenej efektívnosti závlah.

Stav VP sa môže určit' pomocou tzv. "testu infiltrácie kvapky vody do pôdy" (WDPT). Ak je VP detekovaná, môže byt' upravená pomocou povrchovo aktívnych látok ("surfaktantov") tak, aby sa zvýšila efektívnost' závlahy. Pôdy s kritickým obsahom vody pravdepodobne zostanú vodoodpudivými aj po dlhom období melioračných zásahov aj pre vlhkosti pod touto hranicou. To znamená, že výskyt VP sa dá predpokladat' v oblastiach, kde sa vyskytovala aj predtým, predovšetkým $\mathrm{v}$ suchých oblastiach.

Povrchovo aktívne látky (soil surfactants) sú nástrojom technológie manažmentu pre redukciu a možnú elimináciu výskytu VP a s ňou spojeného preferovaného prúdenia. Výsledkom je udržanie, alebo obnovenie zmáčavosti pôdy, zlepšenie infiltračných vlastností a rovnomernosti rozdelenia koreňov. Celosvetový výskum naznačuje, že niektoré povrchovo aktívne látky môžu upravit' vodoodpudivost' pôdy modifikáciou hydrologických vlastností pôdy obnovením zmáčania, čo vedie k zvýšeniu dynamiky vody, a zvyšujú efektívnost' závlah. D̉alším výskumom manažmentu hydrologických vlastností pôdy povrchovo aktívnymi látkami, vývojom technológií senzorov vody pre riadenie závlah smerujeme k novým a lepším metódam riadenia závlah a ich efektívnosti v krajinných ekosystémoch. 